\title{
Change in the foraging strategy of female South American sea lions (Carnivora: Pinnipedia) after parturition
}

\author{
MASSIMILIANO DRAGO ${ }^{1}$, LUÍS CARDONA $^{1}$, ENRIQUE A. CRESPO ${ }^{2,3}$, \\ NÉSTOR GARCÍA $^{2}$, SANTIAGO AMEGHINO ${ }^{3}$ and ALEX AGUILAR ${ }^{1}$ \\ ${ }^{1}$ Department of Animal Biology and Biodiversity Research Institute (IRBio), University of Barcelona, Av. Diagonal 645, \\ 08028 Barcelona, Spain. E-mail address: m.drago@ub.edu \\ ${ }^{2}$ Laboratory of Marine Mammals, Centro Nacional Patagonico (CENPAT-CONICET), Blvd. Brown 3600, \\ 9120 Puerto Madryn, Chubut, Argentina. \\ ${ }^{3}$ National University of Patagonia, Blvd. Brown 3700, 9120 Puerto Madryn, Chubut, Argentina.
}

\begin{abstract}
SUMMARY: This study tests the hypothesis that female South American sea lions shift from off-shore, pelagic prey to coastal, benthic prey after parturition in order to reduce the foraging trip duration and hence the time pups remain unattended on the beach during early lactation. The $\delta^{13} \mathrm{C}$ and $\delta^{15} \mathrm{~N}$ values of the serum and blood cells of 26 South American sea lion suckling pups from northern Patagonia were used to track the dietary changes of their mothers from late pregnancy to early lactation, after correction for differential isotopic fractionation between tissues. Primary producers and potential prey species were also analysed to establish a baseline for interpreting the stable isotope concentration of serum and blood cells. Isotopic ratios revealed a generalized increase in the consumption of coastal-benthic prey after parturition. Such a generalized postpartum shift will allow females to spend more time on land and look after their pups. The effects of this foraging strategy on the nutritional quality of the female's diet are discussed.
\end{abstract}

Keywords: South American sea lion, diet, feeding strategy, suckling pup, lactating females, Otaria flavescens, stable isotopes, Bayesian mixing models.

RESUMEN: CAMBIO EN LA ESTRATEGIA DE ALIMENTACIÓN DE LAS HEMBRAS DEL LEÓN MARINO SUDAMERICANO (CARNIVORA: PINNIPEDIA) TRAS EL PARTO. - El presente estudio pretende comprobar si las hembras del león marino sudamericano adoptan una dieta más bentónica y costera tras el parto, con el fin de reducir la duración de los viajes de alimentación y reducir así el tiempo durante el cual las crías permanecen desatendidas en la playa. Para ello, se determinaron las concentraciones de isótopos estables de carbono y nitrógeno en el suero y las células sanguíneas de 26 crías lactantes de león marino sudamericano del norte de la Patagonia, con el fin de reconstruir la dieta de la madre durante la parte final de la gestación y el inicio de la lactancia, tras la correspondiente corrección del fraccionamiento isotópico entre tejidos. También se analizaron muestras de productores primarios y de presas potenciales para ayudar en la interpretación de los resultados. Las concentraciones de isótopos estables antes y después del parto confirmaron un incremento en el consumo de presas bentónicas costeras tras el parto. Este cambio generalizado de dieta tras el parto permitiría a las hembras incrementar el tiempo que pasan junto a las crías. Se discuten los efectos que esta estrategia puede tener sobre la calidad de la dieta de las hembras.

Palabras clave: león marino sudamericano, dieta, estrategias tróficas, lactancia, Otaria flavescens, isótopos estables, modelos de mezcla bayesianos.

\section{INTRODUCTION}

Otariids are income breeders and females alternate feeding trips to the sea with suckling bouts on land dur- ing the lactation period (Riedman, 1990). Pups remain unattended while their mothers are at sea and may die of starvation (Soto et al., 2004; Reid and Forcada, 2005) or because of the agonistic behaviour of other adults in 
the colony (Campagna et al., 1988; Higgins and Tedman, 1990). In this scenario, lactating otariid females are expected to modify their foraging behaviour (prey choice, time spent foraging) in order to make foraging trip duration as short as possible while they are feeding pups more or less continuously to meet their energy requirements (Costa, 2008). These trade-offs may constrain otariid females to forage closer to the rookery during early lactation, thus promoting a dietary shift after parturition that may lead them to exploit prey not consumed throughout the year (Merrick and Loughlin, 1997; Boyd et al., 2002).

The South American sea lion (Otaria flavescens) exploits an ample range of coastal and off-shore prey in the southwestern Atlantic, foraging close to both the sea bed and the surface of the water column (Werner and Campagna, 1995; Thompson et al., 1998; Koen Alonso et al., 2000; Campagna et al., 2001). Stable isotope analysis has revealed that off northern Patagonia adult females consume more pelagic prey than adult males throughout the year (Drago et al., 2009a). However, stomach content analyses of dead females stranded primarily in summer indicate that their main prey at that time are coastal, benthic fishes and cephalopods (Koen Alonso et al., 2000). This apparently contradictory result could be explained if females behave for most of the year as epipelagic predators and then shift to coastal, benthic prey after parturition. Occasional observations of South American sea lion females close to the edge of the shelf during late summer suggest that their foraging ranges may expand as pups become less dependent (J.F. Mermoz, pers. comm. in Campagna et al., 2001), but further research is needed to clarify the situation.

Although a combination of methods is often the best approach for dietary studies, diet determination based on stomach content or scat analyses is not appropriate to test the above-mentioned hypothesis since these methods provide only a single "snapshot" of the diet of each individual just before sampling. Furthermore, repeated sampling of large animals for stomach content analysis is extremely difficult and being able to assign scats to particular individuals is highly unlikely in crowded rookeries. Conversely, stable isotope analysis offers a suitable alternative because the consumer's tissues reflect those of its prey in a predictable manner over a long period of time (DeNiro and Epstein, 1978, 1981). The blood isotopic signal of suckling pups of pinnipeds and other mammals and that of their mothers are positively and linearly correlated, although some fractionation exists (Jenkins et al., 2001; Ducatez et al., 2008). Hence, the isotopic signal of pup tissues would reflect that of the mother's diet, after correcting the prey-to-predator and mother-to-pup fractionations. Pups of the South American sea lions enter water for the first time when they are about 3 or 4 weeks old (Campagna, 1985) and milk is their exclusive diet for at least the first three weeks of life, although the whole lactation period lasts approximately one year (Riedman, 1990). Furthermore, as serum and blood cells differ in isotopic turnover rate, serum half-life in endotherms being 3-4 days and that of blood cells 2830 days (Hobson and Clark, 1993; Hilderbrand et al., 1996), the isotopic signal of blood cells collected just after birth and that of serum collected three weeks later can be used respectively to infer the female diet in late pregnancy and early lactation.

In this paper, carbon and nitrogen stable isotopes of blood from suckling pups were used to reconstruct the diet of South American sea lion females during late pregnancy and early lactation and to test the hypothesis that a diet change from off-shore, pelagic prey to coastal, benthic coastal occurs in lactating South American sea lion females.

\section{MATERIALS AND METHODS}

\section{Study area}

The present study was conducted in Punta León $\left(43^{\circ} 06^{\prime} \mathrm{S}, 64^{\circ} 29^{\prime} \mathrm{W}\right)$, a provincial reserve, which is located on the Atlantic coast of Argentina, $25 \mathrm{~km}$ south of Golfo Nuevo and about $80 \mathrm{~km}$ from the city of Puerto Madryn, in the Chubut Province (Fig. 1). Punta León is currently one of the settlements of the species with the highest rate of annual growth and one of the most important breeding areas in northern Patagonia (Dans et al., 2004). During the last decade, the breeding area of Punta León has changed considerably, increasing both in number of pups and area of occupation, and new breeding areas have developed to the south of the traditional area (Dans et al., 2004; Grandi et al., 2008). The new breeding areas have a social structure different from the traditional one, as described by Campagna and Le Boeuf (1988), the proportion of juveniles of both sexes and of subadult males being higher (Grandi et al., 2008).

\section{Sampling}

Sampling was carried out during the 2006 breeding season, from the beginning of January to mid-February, the period when most births are registered (Campagna, 1985). Twenty-six one-week-old pups (11 males and 15 females) were captured at random using a noose pole (Gentry and Holt, 1982) and about 2-5 ml of blood was extracted from the caudal gluteal vein in the lumbar region (Geraci and Lounsbury, 1993). Pups were also sexed, bleach-marked (Campagna et al., 2001) and finally released close to their mothers. The entire operation took about 10-15 min for each pup. All pups were found to be readily accepted and nursed by their mother, and all of them survived to the end of the study. Two weeks after the first sampling the same pups were recaptured to extract a second blood sample.

The blood samples were centrifuged in situ at 4000 $\mathrm{x} \mathrm{G}$ for 10 min without anticlotting factors to separate serum and blood cells (Cunningham, 2003). Anticlotting factors were not employed to avoid the alteration of the isotopic signal (Bosley and Wainright, 1999). 


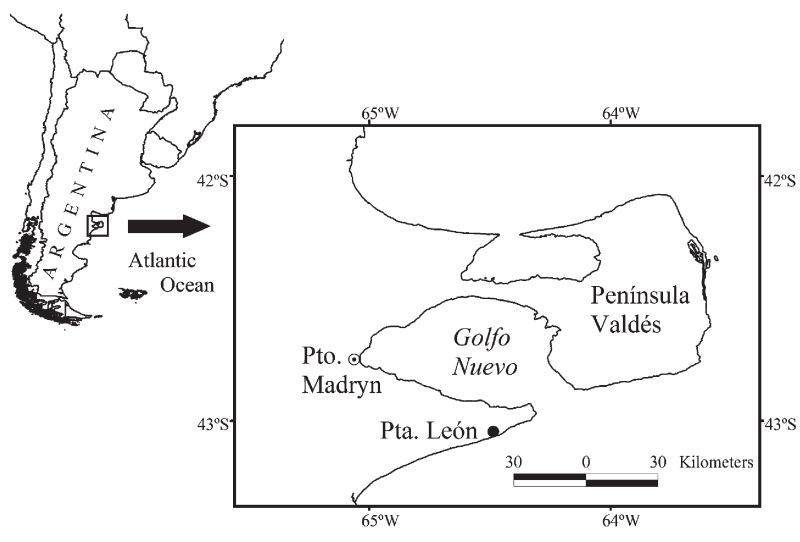

FIG. 1. - Study area.

Serum and blood cells were stored in liquid nitrogen and later in a freezer at $-20^{\circ} \mathrm{C}$ until they were used for stable isotope analysis.

Samples of nine main potential prey species for South American sea lion females off the Chubut province (Koen Alonso et al., 2000) were collected from the zone in January and February 2006 to determine their isotopic signals (Table 1). Off-shore pelagic potential prey species were represented by Argentine anchovy (Engraulis anchoita), Argentine hake (Merluccius hubbsi; two size classes: total length $<30 \mathrm{~cm}$ and total length $>30 \mathrm{~cm}$ ), Argentine short-fin squid (Illex argentinus), South American long-fin squid (Loligo sanpaulensis) and Patagonian squid (Loligo gahi). M. hubbsi was classified as a pelagic species because it consumes mainly pelagic prey (Angelescu and Fuster de Plaza, 1965) and hence its assimilated nutrients are derived from the pelagic food web, although it rests on the seabed during daylight hours. Costal benthic potential prey species were represented by flounder (Paralichthys isosceles), banded cusk ell (Raneya brasiliensis), red octopus (Enteroctopus megalocyathus) and tehuelche octopus (Octopus tehuelchus). White muscle and mantle were collected from fish and cephalopods, respectively. Furthermore samples of benthic primary producers (Codium vermilara and Undaria pinnatifida) and phytoplankton (diatoms and dinoflagellates) were also collected to determine their isotopic signals and hence allow a better interpretation of isotopic results off the Chubut province. Samples of potential prey items and primary producers were provided by local fishermen or collected on board by the staff of the Laboratory of Marine Mammals of the Centro Nacional Patagónico (CENPAT). Phytoplankton was collected with a $20 \mu \mathrm{m}$ mesh-size plankton net and, once in the laboratory, filtered in a precombusted $\mathrm{GF} / \mathrm{C}$ filter. All samples were stored in a freezer at $-20^{\circ} \mathrm{C}$ until analysis.

\section{Stable isotope analyses}

Once in the laboratory, samples were thawed, dried in a stove at $60^{\circ} \mathrm{C}$ for $36 \mathrm{~h}$, and ground into a fine powder using a mortar and pestle. Lipids were extracted with a chloroform/methanol (2:1) solution (Bligh and Dyer, 1959), because lipids are depleted in ${ }^{13} \mathrm{C}$ compared with other molecules, thus confounding the results by decreasing the $\delta^{13} \mathrm{C}$ signal (DeNiro and Epstein, 1977). As phytoplankton samples contain a high concentration of inorganic carbon that may add undesirable variability to $\delta^{13} \mathrm{C}$ (Lorrain et al., 2003), they were previously treated by soaking for $24 \mathrm{~h}$ in $0.05 \mathrm{~N}$ hydrochloric acid $(\mathrm{HCl})$ to decarbonize them (Ogawa and Ogura, 1997). Since $\mathrm{HCl}$ treatment adversely affects $\delta^{15} \mathrm{~N}$ (Bunn et al., 1995), each of the samples was divided into two sub-samples, one used for $\mathrm{C}$ analyses after decarbonation, and the other for $\mathrm{N}$ analyses without decarbonation.

Approximately $0.3 \mathrm{mg}$ of serum, $0.25 \mathrm{mg}$ of blood cells, $4.0 \mathrm{mg}$ of homogenized seaweeds, $16.0 \mathrm{mg}$ of homogenized phytoplankton with filter, and $0.6 \mathrm{mg}$ of white muscle from fish and mantle from cephalopods were weighed into tin cups $(3.3 \times 5 \mathrm{~mm})$, combusted at $900^{\circ} \mathrm{C}$ and analyzed in a continuous flow isotope ratio mass spectrometer (Flash 1112 IRMS Delta C Series EA; Thermo Finnigan, Bremen, Germany). Atropine was used as a system check for elemental analyses. Samples were processed at Serveis Cientificotècnics de la Universitat de Barcelona.

Stable isotope abundances, expressed in delta $(\delta)$ notation, where the relative variations of stable isotope ratios are expressed in per mil (\%o) deviations from predefined international standards, were calculated as:

$$
\delta X=\left[\left(R_{\text {sample }} / R_{\text {standard }}\right)-1\right] 10^{3}
$$

where $X$ is ${ }^{13} \mathrm{C}$ or ${ }^{15} \mathrm{~N}, R_{\text {sample }}$ is the heavy-light isotope ratio of the sample $\left({ }^{13} \mathrm{C} /{ }^{12} \mathrm{C}\right.$ or $\left.{ }^{15} \mathrm{~N} /{ }^{14} \mathrm{~N}\right)$, and $R_{\text {standard }}$ is the heavy-light isotope ratio in reference standards, which were the V-PDB (Vienna Pee Dee Belemnite) calcium carbonate for ${ }^{13} \mathrm{C}$ and atmospheric nitrogen (air) for ${ }^{15} \mathrm{~N}$. International stable isotope secondary standards of known ${ }^{13} \mathrm{C} /{ }^{12} \mathrm{C}$ ratios, as given by the International Atomic Energy Agency (IAEA, Vienna, Austria), namely polyethylene (IAEA $\mathrm{CH}_{7}, \delta^{13} \mathrm{C}=$ $-31.8 \%$ ), graphite (IAEA $\mathrm{USGS}_{24}, \delta^{13} \mathrm{C}=-16.1 \%$ ), and sucrose (IAEA $\mathrm{CH}_{6}, \delta^{13} \mathrm{C}=-10.4 \%$ ), were used for calibration at a precision of $0.2 \%$. For nitrogen, international stable isotope secondary standards of known ${ }^{15} \mathrm{~N} /{ }^{14} \mathrm{~N}$ ratios, namely $\left(\mathrm{NH}_{4}\right)_{2} \mathrm{SO}_{4}$ (IAEA $\mathrm{N}_{1}$, $\delta^{15} \mathrm{~N}=+0.4 \%$ and IAEA $\mathrm{N}_{2}, \delta^{15} \mathrm{~N}=+20.3 \%$ ) , and $\mathrm{KNO}_{3}\left(\right.$ IAEA $\mathrm{NO}_{3}, \delta^{15} \mathrm{~N}=+4.7 \%$ ), were used to a precision of $0.3 \%$.

\section{Data analyses}

Prior to any statistical analysis, normality in data distribution was tested by Lilliefors's test. When required, homogeneity of variances was tested by Levene's contrast test. Nested ANOVA was used to compare the isotopic signal $\left(\delta^{13} \mathrm{C}\right.$ and $\left.\delta^{15} \mathrm{~N}\right)$ and elemental concentration ( $\mathrm{C}$ and $\mathrm{N}$ ) in coastal benthic and off-shore pelagic potential prey species. 
The Student's $t$ test was used to investigate differences in the isotope signals $\left(\delta^{13} \mathrm{C}\right.$ and $\left.\delta^{15} \mathrm{~N}\right)$ in serum and blood cells of male and female pups. The same procedure was used to investigate differences between blood cell $\delta^{13} \mathrm{C}$ and serum $\delta^{13} \mathrm{C}$ and between blood cell $\delta^{15} \mathrm{~N}$ and serum $\delta^{15} \mathrm{~N}$ of pups, once corrected in accordance with the expected total diet-to-pup isotopic enrichment.

The Bayesian mixing model SIAR (Stable Isotope Analysis in R; Parnell et al., 2008) was used to calculate the relative contribution of the potential prey to the female's diet before and after parturition (i.e. in late pregnancy and early lactation). Bayesian approaches allow incorporating not only isotopic values, elemental concentrations and fractionation factors within the mixing models, but also the uncertainties involved in all these values, thus providing results that are considerably more robust for quantifying feeding preferences than those in previous modelling approaches (Inger and Bearhop, 2008; Moore and Semmens, 2008; Parnell et al., 2008; Jackson et al., 2009). Furthermore, as the resulting later distributions of the proportions of various sources within the diet of a consumer have associated probabilities, we can use the most likely solution as a single metric for a given dietary component in subsequent analyses (Inger and Bearhop, 2008; Moore and Semmens, 2008; Jackson et al., 2009).

The model parameters were the isotope ratios and the elemental concentrations of the potential food sources, the isotope ratio of pup blood cells and serum and the trophic shift, or isotopic enrichment, for carbon and nitrogen from prey to predator. Prey-to-predator isotopic enrichment in lactating female otariids has been reported to be $3.9 \%$ o for serum $\delta^{15} \mathrm{~N}, 0.2 \%$ or serum $\delta^{13} \mathrm{C}, 3.5 \%$ o for blood cell $\delta^{15} \mathrm{~N}$ and $1.2 \%$ or bo blood cell $\delta^{13} \mathrm{C}$ (Kurle, 2002). The mother-to-pup isotopic transfer is known to cause a further isotopic enrichment of $0.9 \%$ or serum $\delta^{15} \mathrm{~N}$, but no enrichment for serum $\delta^{13} \mathrm{C}$ and for blood cell $\delta^{15} \mathrm{~N}$ and $\delta^{13} \mathrm{C}$ (Jenkins et al., 2001). Thus, the total diet-to-pup fractionation is expected to be $4.8 \%$ o for serum $\delta^{15} \mathrm{~N}$ and $0.2 \%$ o for serum $\delta^{13} \mathrm{C}, 3.5 \%$ o for blood cell $\delta^{15} \mathrm{~N}$ and $1.2 \%$ o for blood cell $\delta^{13} \mathrm{C}$. As serum and blood cells differ in the isotopic turnover rate (Hobson and Clark, 1993; Hilderbrand et al., 1996), blood cells from one-week-old pups were used to infer the female diet in the late pregnancy period and serum from three-week-old pups was used to infer the diet of females when feeding after parturition.

Data are usually shown as mean \pm standard deviation (SD), but the feasible contribution of potential prey species to the female diet is reported as mean and the 95\% credibility interval. All statistical analyses were conducted with the SPSS 15 software package, except the Bayesian mixing model, which was conducted with the SIAR software package (Parnell et al., 2008).

\section{RESULTS}

Table 1 shows the concentration of stable isotopes of carbon and nitrogen in the local primary producers, the potential prey, and the pups analyzed. Only the stable isotope values of blood cells from the one-week-

TABLE 1. - Stable isotope values (mean $\pm \mathrm{SD}$ ) of the South American sea lion pups, the potential prey of their mothers and primary producers. Habitat type: pelagic (P) and benthic (B). Sample size (n)

\begin{tabular}{|c|c|c|c|c|c|}
\hline Scientific name & Common name & Habitat & $n$ & $\delta^{13} \mathrm{C}(\% \circ)$ & $\delta^{15} \mathrm{~N}(\% \circ)$ \\
\hline \multicolumn{6}{|l|}{ Primary producers } \\
\hline Phytoplankton & & $\mathrm{P}$ & $2^{\mathrm{a}}$ & $-21.0 \pm 0.1$ & $13.4 \pm 0.6$ \\
\hline \multicolumn{6}{|l|}{ Seaweed } \\
\hline Codium vermilara & & B & 5 & $-14.9 \pm 1.3$ & $11.6 \pm 0.4$ \\
\hline Undaria pinnatifida & wakame & $\mathrm{B}$ & 5 & $-19.1 \pm 1.2$ & $10.4 \pm 0.5$ \\
\hline \multicolumn{6}{|l|}{ Potential prey } \\
\hline \multicolumn{6}{|l|}{ Fish } \\
\hline Engraulis anchoita & Argentine anchovy & $\mathrm{P}$ & 5 & $-17.9 \pm 0.2$ & $15.7 \pm 0.8$ \\
\hline Merluccius hubbsi ${ }^{(>30 \mathrm{~cm})}$ & Argentine hake & $\mathrm{P}$ & 5 & $-17.0 \pm 0.5$ & $17.1 \pm 0.4$ \\
\hline Merluccius hubbsi ${ }^{(<30 \mathrm{~cm})}$ & Argentine hake & $\mathrm{P}$ & 5 & $-17.7 \pm 0.6$ & $15.9 \pm 0.5$ \\
\hline Paralichthys isosceles & Flounder & B & 5 & $-15.9 \pm 0.4$ & $18.0 \pm 0.6$ \\
\hline Raneya brasiliensis & Banded cusk eel & B & 5 & $-15.3 \pm 0.6$ & $18.8 \pm 0.5$ \\
\hline \multicolumn{6}{|l|}{ Cephalopods } \\
\hline Illex argentinus & Argentine short-fin squid & $\mathrm{P}$ & 5 & $-17.0 \pm 0.6$ & $13.7 \pm 0.8$ \\
\hline Loligo sanpaulensis & South American long-fin squid & $\mathrm{P}$ & 5 & $-16.8 \pm 0.2$ & $17.2 \pm 0.3$ \\
\hline Loligo gahi & Patagonian squid & $\mathrm{P}$ & 4 & $-17.6 \pm 0.4$ & $15.7 \pm 0.6$ \\
\hline Enteroctopus megalocyathus & Red octopus & $\mathrm{B}$ & 5 & $-14.6 \pm 0.7$ & $18.9 \pm 0.9$ \\
\hline Octopus tehuelchus & Tehuelche octopus & $\mathrm{B}$ & 5 & $-14.8 \pm 0.2$ & $19.9 \pm 0.4$ \\
\hline \multicolumn{6}{|l|}{ Sea lion pups } \\
\hline \multicolumn{6}{|l|}{ Mammals } \\
\hline \multirow[t]{2}{*}{ Otaria flavescens } & South American sea lion & & $26^{\mathrm{b}}$ & $-15.7 \pm 0.3$ & $20.9 \pm 0.6$ \\
\hline & & & $26^{c}$ & $-15.8 \pm 0.3$ & $23.1 \pm 0.6$ \\
\hline Benthic prey ${ }^{d}$ & & & 4 & $-15.1 \pm 0.6$ & $18.9 \pm 0.8$ \\
\hline Pelagic prey & & & 6 & $-17.3 \pm 0.5$ & $15.9 \pm 1.3$ \\
\hline
\end{tabular}

a, Collective samples of diatoms and dinoflagellates, including several individuals.

b, Stable isotope value of pup blood cells from the first week.

c, Stable isotope value of pup serum from the third week.

d, Gross mean of the benthic prey. Sample size refers to the number of species.

e, Gross mean of the pelagic prey. Sample size refers to the number of species. 


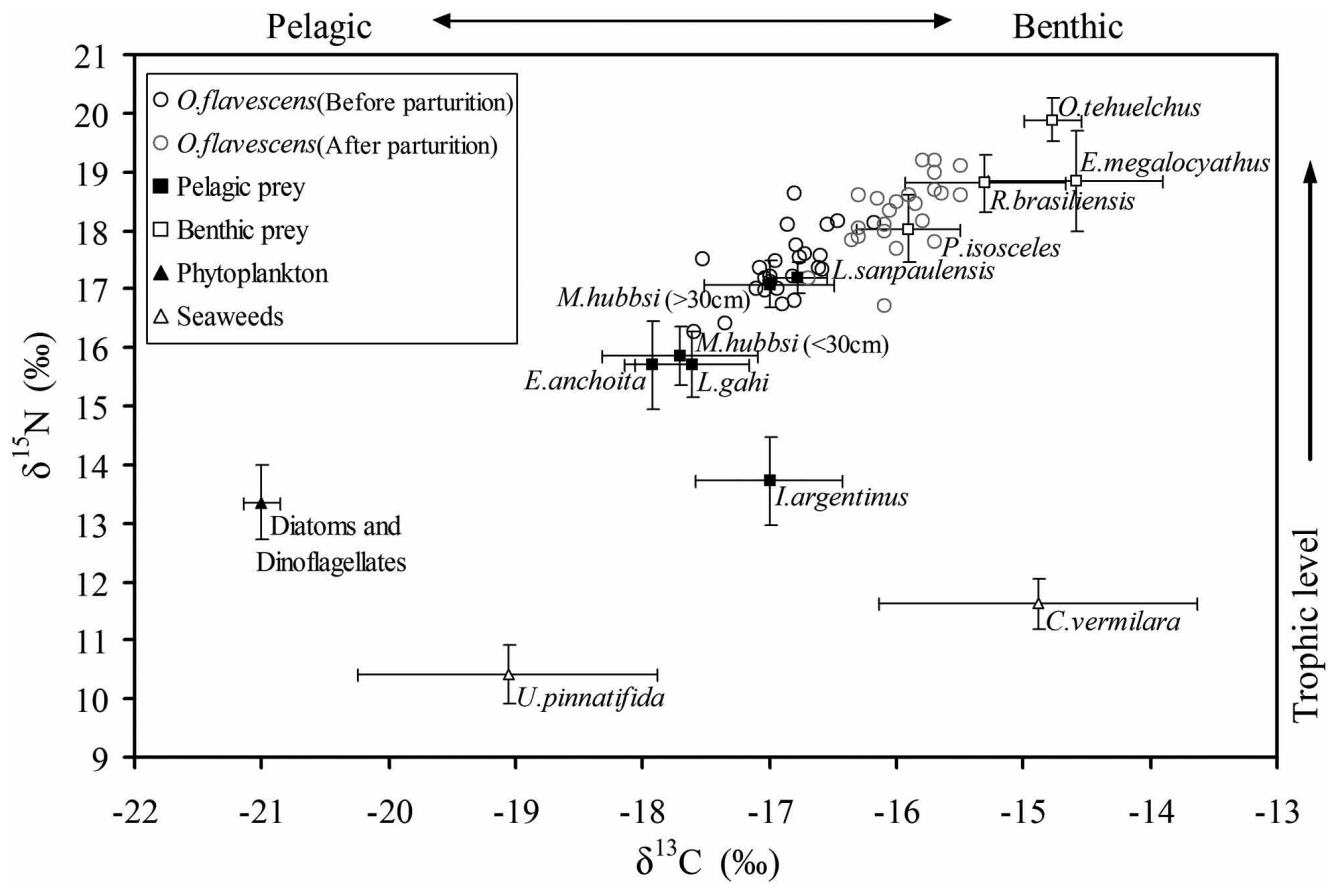

FIG. 2. - Bivariated isotopic signals of South American sea lion pups before and after parturition, once corrected in accordance with the expected total diet-to-pup isotopic enrichment for blood cells (before parturition) and serum (after parturition). Bivariated isotopic signals of the main potential prey of sea lion females and the primary producers shown as mean $\pm \mathrm{SD}$. Sample size $n=5$ for all the species, except for $O$. flavescens ( $n=26$ for each tissue), L. gahi $(n=4)$ and phytoplankton $(n=2$; collective samples of diatoms and dinoflagellates).

old pups and those of serum from the three-week-old pups were analyzed. The stable isotope values of serum from the one-week-old pups and those of blood cells from the three-week-old pups were not analyzed as they are expected to be influenced both by the diet just before parturition and by the changes that might happen after parturition, thus obscuring interpretation.

The $\delta^{15} \mathrm{~N}$ of potential prey increased with trophic level and benthic primary producers were more enriched in ${ }^{13} \mathrm{C}$ than pelagic ones (Fig. 2). As a conse-

TABLE 2. - Summary of nested ANOVA results to test for differences in the isotopic signal $\left(\delta^{13} \mathrm{C}\right.$ and $\left.\delta^{15} \mathrm{~N}\right)$ and elemental concentration $(\mathrm{C}$ and $\mathrm{N}$ ) of the considered prey species within habitat (benthic vs pelagic).

\begin{tabular}{|c|c|c|c|c|c|c|}
\hline & SS & df & MS & $F$ & $P$ & $r^{2}$ \\
\hline \multicolumn{7}{|l|}{$\delta^{13} \mathbf{C}(\% o)$} \\
\hline Model & 66.950 & 9 & 7.439 & 30.903 & $<0.001$ & 0.877 \\
\hline Intersect & 12659.920 & 1 & 12659.920 & 52592.339 & $<0.001$ & \\
\hline Habitat & 56.610 & 1 & 56.610 & 235.170 & $<0.001$ & \\
\hline Species(Habitat) & 10.644 & 8 & 1.331 & 5.527 & $<0.001$ & \\
\hline Error & 9.388 & 39 & 0.241 & & & \\
\hline Total & 13321.060 & 49 & & & & \\
\hline \multicolumn{7}{|l|}{$\delta^{15} \mathbf{N}(\% o)$} \\
\hline Intersect & $\begin{array}{c}155.593 \\
14340.188\end{array}$ & 9 & $\begin{array}{c}17.288 \\
14340.188\end{array}$ & $\begin{array}{r}51.296 \\
42549248\end{array}$ & $<0.001$ & 0.922 \\
\hline Habitat & 107.413 & 1 & 107.413 & 318.709 & $<0.001$ & \\
\hline Species(Habitat) & 48.302 & 8 & 6.038 & 17.915 & $<0.001$ & \\
\hline Error & 13.144 & 39 & 0.337 & & & \\
\hline Total & 14510.510 & 49 & & & & \\
\hline \multicolumn{7}{|l|}{$\mathrm{C}(\%)$} \\
\hline Model & 153.412 & 9 & 17.046 & 19.468 & $<0.001$ & 0.818 \\
\hline Intersect & 87047.305 & 1 & 87047.305 & 99417.085 & $<0.001$ & \\
\hline Habitat & 12.220 & 1 & 12.220 & 13.957 & 0.001 & \\
\hline Species(Habitat) & 140.172 & 8 & 17.522 & 20.011 & $<0.001$ & \\
\hline Error & 34.148 & 39 & 0.876 & & & \\
\hline Total & 89930.600 & 49 & & & & \\
\hline \multicolumn{7}{|l|}{$\mathrm{N}(\%)$} \\
\hline Model & 10.859 & 9 & 1.207 & 18.074 & $<0.001$ & 0.807 \\
\hline Intersect & 9271.528 & 1 & 9271.528 & 138886.01 & $<0.001$ & \\
\hline Habitat & 0.212 & 1 & 0.212 & 3.183 & 0.082 & \\
\hline Species(Habitat) & 10.621 & 8 & 1.328 & 19.887 & $<0.001$ & \\
\hline Error & 2.604 & 39 & 0.067 & & & \\
\hline Total & 9547.590 & 49 & & & & \\
\hline
\end{tabular}




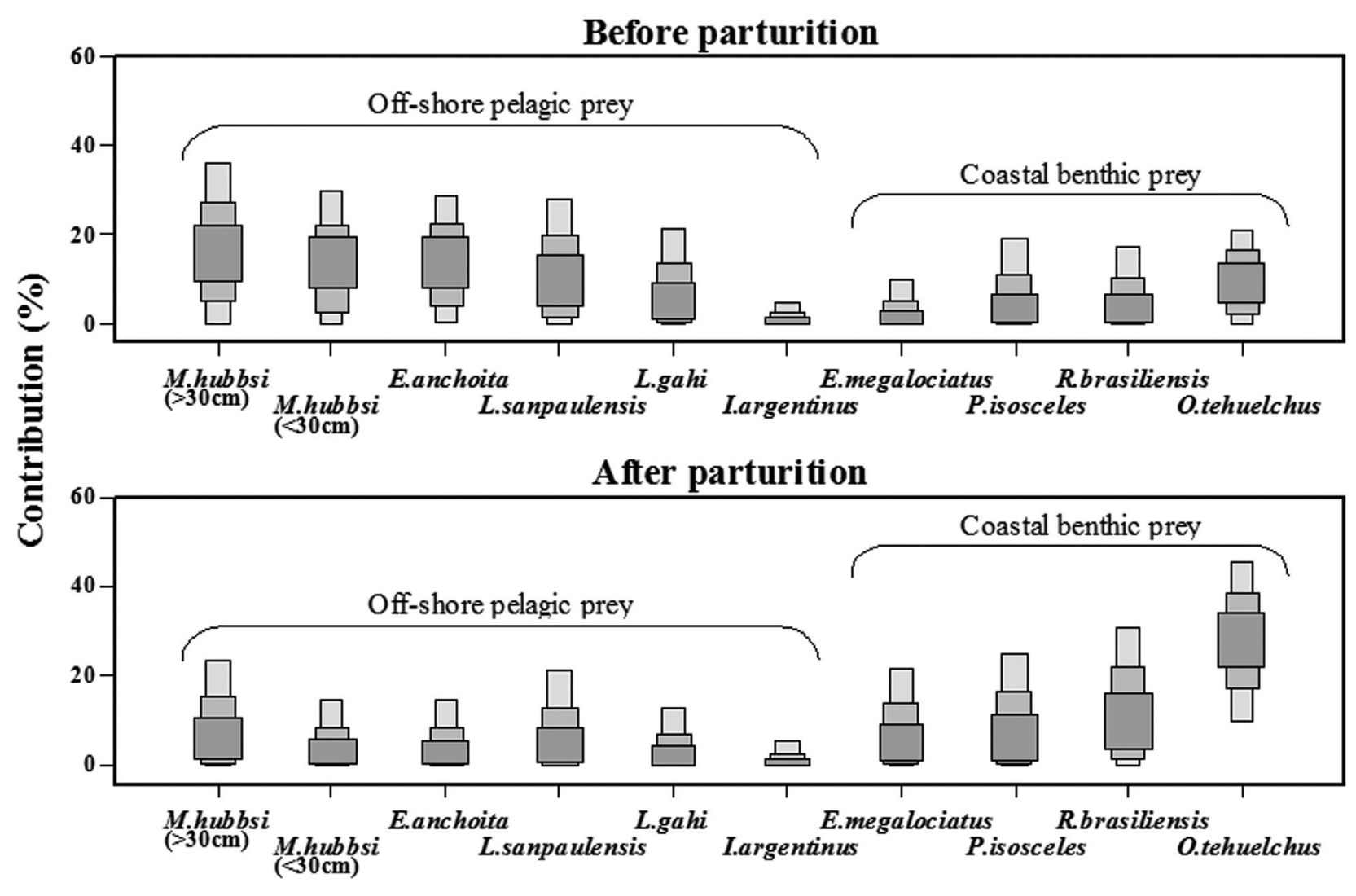

FIG. 3. - Contribution of each of the main potential prey to the female sea lion diet before (upper panels) and after parturition (lower panels), as determined by SIAR mixing model, using the isotopic signals of pup blood cells from the first week and serum from the third week respectively. Each prey species shows $95 \%, 75 \%$ and $50 \%$ credibility intervals for the calculated feasible contribution to the female sea lion diet.
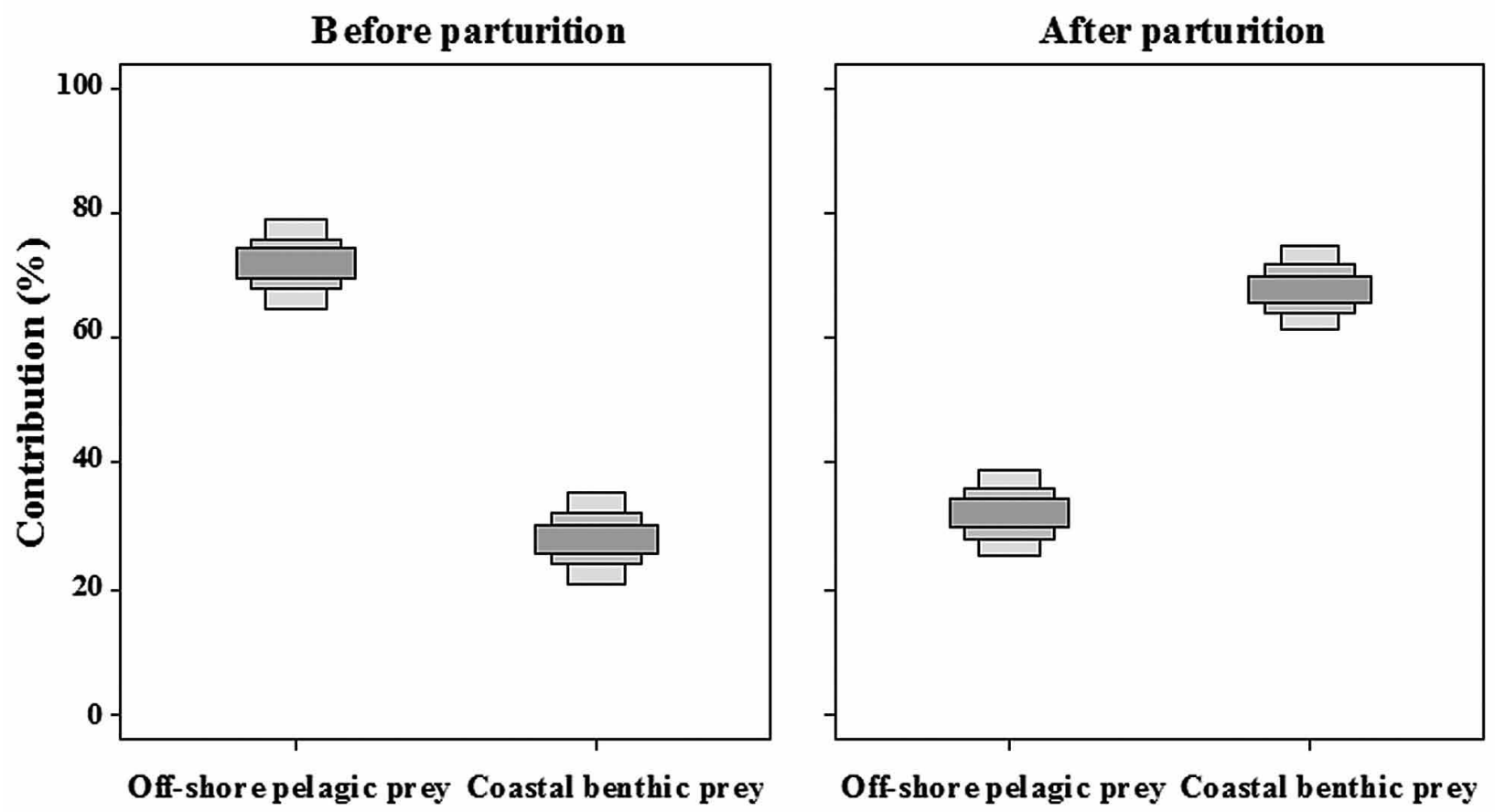

FIG. 4. - Contribution of the potential prey from off-shore, pelagic and coastal, benthic habitats to the female sea lion diet before (left panel) and after parturition (right panel), as determined by the SIAR mixing model using the isotopic signals of pup blood cells from the first week and serum from the third week, respectively. The contribution of each group of prey to the female sea lion diet is shown with $95 \%$, $75 \%$ and $50 \%$ credibility intervals. 
quence, benthic potential preys were more enriched in ${ }^{13} \mathrm{C}$ and ${ }^{15} \mathrm{~N}$ than pelagic ones (Table 1), as confirmed by nested ANOVA (Table 2). Differences existed among prey in elemental concentrations of carbon and nitrogen, but they were related to habitat only for carbon (Table 2).

The pup sex had no statistically significant effect on serum $\delta^{13} \mathrm{C}$ (males: $-15.9 \pm 0.2 \%$ o, females: -15.7 $\pm 0.3 \%$; $t=-1.243$, df $=24, P=0.226$ ), serum $\delta^{15} \mathrm{~N}$ (males: $22.9 \pm 0.6 \%$, females: $23.3 \pm 0.6 \%$; $t=-1.595$, $\mathrm{df}=24, P=0.124$ ), blood cell $\delta^{13} \mathrm{C}$ (males: $-15.6 \pm$ $0.2 \%$, females: $-15.7 \pm 0.4 \%$; $t=0.545, \mathrm{df}=24, P=$ 0.591 ) and blood cell $\delta^{15} \mathrm{~N}$ (males: $20.8 \pm 0.4 \%$ o, females: $20.9 \pm 0.7 \%$; $t=-0.536, \mathrm{df}=24, P=0.597)$. As a consequence, male and female pups were pooled for latter analyses.

Comparison between the stable isotope values of blood cells collected when pups were one week old and those of the serum collected when pups were three weeks old, after correction for the expected diet-to-pup isotopic enrichment, revealed that corrected serum isotopic values $\left(\delta^{13} \mathrm{C}:-16.0 \pm 0.3 \% ; \delta^{15} \mathrm{~N}: 18.3 \pm\right.$ $0.6 \%$ o) were on average more enriched in both ${ }^{13} \mathrm{C}(t$ $=-19.223$, df $=25, P<0.001)$ and ${ }^{15} \mathrm{~N}(t=-9.177, \mathrm{df}=$ $25, P<0.001)$ than corrected blood cell isotopic values $\left(\delta^{13} \mathrm{C}:-16.9 \pm 0.3 \%\right.$; $\delta^{15} \mathrm{~N}: 17.4 \pm 0.6 \%$ o $)$. This result is consistent with a diet including more costal, benthic prey species once females resume foraging after parturition (Fig. 2).

The results of SIAR indicated that Merluccius hubbsi of any size, Engraulis anchoita and Loligo sanpaulensis were the most important prey before parturition. This pattern was reversed after parturition, when females relied heavily on Octopus tehuelchus and other costal benthic prey (Fig. 3). As a consequence, the contribution of off-shore, pelagic potential prey to the nutrients assimilated by the females before parturition was higher than that observed after parturition (before, mean $=72 \%, 95 \%$ credibility interval $65-79 \%$; after, mean $=32 \%, 95 \%$ credibility interval $25-39 \%$ ), whereas the opposite was true for costal benthic potential prey (before, mean $=28 \%, 95 \%$ credibility interval $21-35 \%$; after, mean $=68 \%, 95 \%$ credibility interval 61-75\%) (Fig. 4).

\section{DISCUSSION}

In recent years stable isotopes have become a standard tool for investigating trophic relationship of wild animals (Crawford et al., 2008). Their use is based on three assumptions: (1) that carbon and nitrogen in the body of an animal come directly from its food and, as a consequence, the tissue isotopic signal can be used to ascertain the relative importance of feeding sources that differ in signal (DeNiro and Epstein, 1978, 1981); (2) that the assimilated organic substance gets richer in the heavy isotopes of both $\mathrm{C}$ and $\mathrm{N}$ when passing from a trophic level to the following one, although that enrichment is greater for nitrogen than for carbon (Michener and Schell, 1994); and (3) that the change rate of the isotopic signal of each tissue depends on its metabolic rate and, hence, the time reference of dietary information is tissuedependent (Michener and Schell, 1994).

Neither prey-to-predator and female-to-offspring enrichment rates nor the tissue turnover have been determined for the South America sea lion in controlled experiments and hence extrapolation from studies conducted on phylogenetically close organisms is required (Lewis et al., 2006; Hückstädt et al., 2007). Fortunately, the prey-to-predator enrichment rate has been determined in other pinnipeds in captivity (Hobson et al., 1996; Kurle, 2002), the female-to-offspring enrichment rate has been assessed in other carnivores, including pinnipeds (Jenkins et al., 2001; Ducatez et al., 2008), and the turnover rate of blood components has been established for a number of birds and mammals (Hobson and Clark, 1993; Hilderbrand et al., 1996). We have used the results of these studies to interpret the values found here, but caution is needed and all the results should be considered as an approximation.

The stable isotope landscape of northern Patagonia and SIAR revealed Merluccius hubbsi as one of the main prey of female South American sea lions in Patagonia before parturition, which coincides with the findings of stomach content analyses previously conducted on stranded individuals from the same region (Koen Alonso et al., 2000). This confirmation is important, because most analyses of the interaction between South American sea lions and industrial fishing in the south-western Atlantic have focused on the fishery targeting M. hubbsi fishery (Koen Alonso and Yodzis, 2005; Drago et al., 2009b). However, SIAR indicates a much higher contribution of Engraulis anchoita and Loligo sanpaulensis to the diet of female South American sea lions during late pregnancy than the stomach content analysis does (Koen Alonso et al., 2000). This is probably because the isotopic signal of $M$. hubbsi shorter than $30 \mathrm{~cm}$ is extremely close to that of $E$. anchoita and the same is true for the isotopic signal of M. hubbsi larger than $30 \mathrm{~cm}$ and that of L. sanpaulensis. As a consequence, SIAR attributes roughly the same relevance in the diet of female South American sea lions to the two members of each of the former groups, although E. anchoita and L. sanpaulensis are much scarcer in stomach contents than $M$. hubbsi of any size. SIAR also indicates a much higher contribution of Octopus tehuelchus to the diet of female South American sea lions after parturition than the stomach content analysis does (Koen Alonso et al., 2000). This is perhaps due to the small size of $O$. tehuelchus compared with Enteroctopus megalocyathus and therefore to the difficulty of identifying the tiny beaks in stomach contents. Alternatively, this discrepancy may indicate a switch in the prey selection, possibly resulting from a change in the abundance or distribution of the two octopus species. 
Whatever the reasons for those contrasting results, the differences between the corrected isotopic signals of serum and blood cells clearly reveal a marked shift after parturition towards coastal, benthic prey to the detriment of off-shore, pelagic prey, as already reported for other pinnipeds (Chilvers et al., 2005). After parturition, lactating females need to satisfy the high energy requirements involved in pup rearing, particularly during the first weeks when they need to provide lipidrich milk to their pups, so they are expected to shift to highly nutritious prey. Pelagic prey off Patagonia usually have a higher energy density than benthic prey (Eder and Lewis, 2005; Drago et al., 2009b, 2010) and hence an increase in the consumption of pelagic prey might be expected. However, the results of the present study reveal an increase in the consumption of benthic species. The energy density of Paralichthys isosceles is similar to that of most pelagic potential prey, but that of Enteroctopus megalocyathus, Octopus tehuelchus and Raneya brasiliensis is much lower (Eder and Lewis, 2005; Drago et al., 2009b, 2010). Some pinniped species rely consistently on large benthic prey because a large individual size results in rewarding meals despite a low energy density (Costa and Gales, 2003; Chilvers et al., 2006). This suggests that lactating South American sea lion females might balance the average lower nutritional quality of coastal, benthic prey by targeting the largest ones. However, SIAR indicates that after parturition lactating South American sea lion females consume large amounts of small benthic species such as $O$. tehuelchus and $R$. brasiliensis instead of larger species such as E. megalocyathus and P. isosceles. The same is true in the Falkland (Malvinas) Islands, where lactating South American sea lion females consume primarily small inshore benthic notothenid fish of unknown energy density (Thompson et al., 1998).

Evidence supporting the hypothesis of a general decline in the nutritional quality of the diet after parturition also comes from studies on milk quality, as the fat content of the milk of female South American sea lions decreases after parturition (Werner et al., 1996), whereas the opposite is true for pinnipeds, which are capital breeders (Riedman, 1990). Furthermore, the pups of the South American sea lion whose mothers maintain a high consumption of off-shore prey in their diets during early lactation grow faster than the pups whose mothers rely on benthic coastal prey (Drago et al., 2010), although nothing is known about the milk quality of lactating females consuming contrasting diets. Drago et al. (2010) demonstrated that differences among pups in fasting time cannot explain the abovereported results because: i) the range of $\delta^{15} \mathrm{~N}$ values in pup blood was much wider than expected accordingly with fasting duration and the documented increase in the $\delta^{15} \mathrm{~N}$ with fasting in endothermic animals, and ii) the $\delta^{13} \mathrm{C}$ decreases with fasting in endothermic animals but it is negatively correlated with pup growth.

Thus, the overall evidence indicates that the dietary shift observed after parturition is inconsistent with a foraging strategy aiming to maximize energy intake. On the contrary, shifting to coastal, benthic prey after parturition may result in a reduction in the foraging trip duration of females, which in turn may result in a decrease in the pup mortality rate. This hypothesis is supported by the results of a telemetry study demonstrating that in northern Patagonia the trip length of lactating females was significantly correlated with the distance travelled, although females travelling off-shore swam faster than those feeding on-shore (Campagna et al., 2001). Furthermore, a positive correlation between the foraging trip length of lactating South American sea lion females and the pup mortality rate has also been reported off Peru (Soto et al., 2004, 2006). In this scenario, the foraging strategy of South American sea lion females after parturition is determined by the trade-offs between the trip length and the nutritional quality of prey. Relying only on coastal, benthic prey of poor nutritional quality will be useful to reduce the foraging trip length and hence the pup mortality during early lactation. However, this foraging strategy will negatively affect the pup growth rate and may increase the mortality rate at weaning if the weight at weaning correlates with the survival rate, as reported for other pinnipeds (McMahon et al., 2000).

\section{ACKNOWLEDGEMENTS}

Thanks are given to the staff of the Marine Mammal Laboratory of the Centro Nacional Patagónico (CENPAT-CONICET), particularly to B. Berón Vera, F. García, M.F. Grandi, S. Leonardi, G.M. Svendsen and D. Vales for overall assistance and logistic support during field work, to N. Ortiz and F. Márquez for assistance in finding the elusive red octopus, to R. Moreno for assistance in the SIAR software, and to C. Gambuzza and J. Babic for assistance with the English language. We also thank the two anonymous referees for their careful revision and useful comments to improve the manuscript. The Spanish Ministry of Education and Science (MEC) supported M.D. through a PhD fellowship. The study was funded by the Fundación BBVA through the project "Estudio de las amenazas para la conservación de mamíferos marinos de Patagonia" (BIOCON 04), Programa Nacional de Biodiversidad, Ciencias de la Tierra y Cambio Global of the Spanish Ministry of Education and Science (MEC) through the project "CGL2005-00922/BOS", GEF/PNUD through the project "Conservación de la Diversidad Biológica Marina y Prevención de la Contaminación en Patagonia" (ARG 02/018) and the Zoo d`Amneville, France

\section{REFERENCES}

Angelescu, V. and M.L. Fuster de Plaza. - 1965. Migraciones verticales rítmicas de la merluza del sector bonaerense (Merluciidae, Merluccius hubbsi) y su significado ecológico. An. Acad. Bras. Cienc., 37: 194-214.

Bligh, E.G. and W.J. Dyer. - 1959. A rapid method of total lipid extraction and purification. Can. J. Biochem. Physiol., 37: 911-917. 
Bosley, K.L. and S.C. Wainright. - 1999. Effects of preservatives and acidification on the stable isotope ratios $\left({ }^{15} \mathrm{~N}:{ }^{14} \mathrm{~N},{ }^{13} \mathrm{C}:{ }^{12} \mathrm{C}\right)$ of two species of marine animals. Can. J. Fish. Aquat. Sci., 56: 2181-2185.

Boyd, I.L., I.J. Staniland and A.R. Martin. - 2002. Distribution of foraging by female Antarctic fur seals. Mar. Ecol. Prog. Ser., 242: $285-294$

Bunn, S.E., N.R. Loneragan and M.A. Kempster. - 1995. Effects of acid washing on stable isotope ratios of $\mathrm{C}$ and $\mathrm{N}$ in penaeid shrimp and seagrass: implications for food-web studies using multiple stable isotopes. Limnol. Oceanogr., 40: 622-625.

Campagna, C. -1985 . The breeding cycle of the southern sea lion, Otaria byronia. Mar. Mamm. Sci., 3: 210-218.

Campagna, C. and B.J. Le Boeuf. - 1988. Reproductive behaviour of southern sea lion. Behaviour, 104: 233-280.

Campagna, C., B.J. Le Boeuf and H.L. Cappozzo. - 1988. Pup abduction and infanticide in southern sea lions. Behaviour, 107 44-60.

Campagna, C., R. Werner, W. Karesh, M.R. Marin, F. Koontz, R. Cook and C. Koontz. - 2001. Movements and location at sea of South American sea lions (Otaria flavescens). J. Zool., 257: 205-220.

Chilvers, B.L., I.S. Wilkinson, P.J. Duignan and N.J. Gemmell. 2005. Summer foraging areas for lactating New Zealand sea lions Phocarctos hookeri. Mar. Ecol. Prog. Ser., 304: 235-247.

Chilvers, B.L., I.S. Wilkinson, P.J. Duignan and N.J. Gemmell. 2006. Diving to extremes: are New Zealand sea lions (Phocarctos hookeri) pushing their limits in a marginal habitat? J. Zool., 269: 233-240.

Costa, D.P. - 2008. A conceptual model of the variation in parental attendance in response to environmental fluctuation: foraging energetics of lactating sea lions and fur seals. Aquat. Conserv.. Mar. Freshw. Ecosyst., 17: S44-S52.

Costa, D.P. and N.J. Gales. - 2003. Energetics of a benthic diver: seasonal foraging ecology of the australian sea lion, Neophoca cinerea. Ecol. Monogr., 73: 27-43.

Crawford, K., A. McDonald and S. Bearhop. - 2008. Applications of stable isotope techniques to the ecology of mammals. Mammal Rev., 38: 87-107.

Cunningham, J.G. - 2003. Fisiología Veterinaria. Elsevier Spain, Madrid.

Dans, S.L., E.A. Crespo, S.N. Pedraza and M. Koen Alonso. - 2004. Recovery of the South American sea lion population (Otaria flavescens) in northern Patagonia. Can. J. Fish. Aquat. Sci., 61: $1681-1690$

DeNiro, M.J. and S. Epstein. - 1977. Mechanism of carbon isotope fractionation associated with lipid synthesis. Science, 197: 261-263.

DeNiro, M.J. and S. Epstein. - 1978. Influence of diet on the distribution of carbon isotopes in animals. Geochim. Cosmochim. Acta, 42: 495-506

DeNiro, M.J. and S. Epstein. - 1981. Influence of diet on the distribution of nitrogen isotopes in animals. Geochim. Cosmochim. Acta, 45: 341-351

Drago, M., L. Cardona, E.A. Crespo and A. Aguilar. - 2009a. Ontogenic dietary changes in South American sea lions. J. Zool., 279: 251-261

Drago, M., E.A. Crespo, A. Aguilar, L. Cardona, N. García, S.L. Dans and N. Goodall. -2009b. Historic diet change of the South American sea lion in Patagonia as revealed by isotopic analysis. Mar. Ecol. Prog. Ser., 384: 273-289.

Drago, M., L. Cardona, A. Aguilar, E.A. Crespo, S. Ameghino and N. García. - 2010. Diet of lactating South American sea lions, as inferred from stable isotopes, influences pup growth. Mar. Mamm. Sci., 26: 309-323.

Ducatez, S., S. Dalloyau, P. Richard, C. Guinet and Y. Cherel. 2008. Stable isotopes document winter trophic ecology and maternal investment of adult female southern elephant seals (Mirounga leonina) breeding at the Kerguelen Islands. Mar. Biol., 155: 413-420.

Eder, E.B. and M.N. Lewis. - 2005. Proximate composition and energetic value of demersal and pelagic prey species from the SW Atlantic Ocean. Mar. Ecol. Prog. Ser., 291: 43-52.

Gentry, R.L. and J.R. Holt. - 1982. Equipment and techniques for handling northern fur seals. NOAA Tech. Rep., 758: 1-15.

Geraci, J.R. and V.J. Lounsbury. - 1993. Marine mammals ashore. A field guide for strandings. Texas A\&M University Sea Grant
College Program, Galveston.

Grandi, M.F., S.L. Dans and E.A. Crespo. - 2008. Social composition and spatial distribution of colonies in an expanding population of South America sea lions. J. Mammal., 89: 1218-1228.

Higgins, L.V. and R.A. Tedman. - 1990. Effects of attacks by male Australian sea lions, Neophoca cinerea, on mortality of pups. $J$. Mammal., 71: 617-619.

Hilderbrand, G.V., S.D. Farley, C.T. Robbins, T.A. Hanley, K. Titus and C. Servheen. - 1996. Use of stable isotopes to determine diets of living and extinct bears. Can. J. Zool., 74: 2080-2088.

Hobson, K.A. and R.G. Clark. -1993 . Turnover of ${ }^{13} \mathrm{C}$ in cellular and plasma fractions of blood: implications for non-destructive sampling in avian dietary studies. Auk, 110: 638-641.

Hobson, K.A., D.M. Schell, D.Y. Renouf and E. Noseworthy. 1996. Stable carbon and nitrogen isotopic fractionation between diet and tissues of captive seals: implications for dietary reconstructions involving marine mammals. Can. J. Fish. Aquat. Sci., 53: 528-533.

Hückstädt, L.A., C.P. Rojas and T. Antezana. - 2007. Stable isotope analysis reveals pelagic foraging by the Southern Sea lion in central Chile. J. Exp. Mar. Biol. Ecol., 347: 123-133.

Inger, R. and S. Bearhop. - 2008. Applications of stable isotope analyses to avian ecology. Ibis, 150: 447-461.

Jackson, A.L., R. Inger, S. Bearhop and A. Parnell. - 2009. Erroneous behaviour of MixSIR, a recently published Bayesian isotope mixing model: a discussion of Moore \& Semmens (2008). Ecol. Lett., 12: E1-E5.

Jenkins, S.G., S.T. Partridge, T.R. Stephenson, S.D. Farley and C.T. Robbins. - 2001. Nitrogen and carbon isotope fractionation between mothers, neonates and nursing offspring. Oecologia, 129: 336-341.

Koen Alonso, M. and P. Yodzis. - 2005. Multispecies modelling of some components of the marine community of northern and central Patagonia, Argentina. Can. J. Fish. Aquat. Sci., 62: 1490-1512.

Koen Alonso, M., E.A. Crespo, S.N. Pedraza, N.A. Garcia and M.A. Coscarella. - 2000. Food habits of the South American sea lion, Otaria flavescens, off Patagonia, Argentina. Fish. Bull., 98: 250-263.

Kurle, C.M. - 2002. Stable-isotope ratios of blood components from captive norther fur seals (Callorhinus ursinus) and their diet: applications for studying the foraging ecology of wild otariids. Can. J. Zool., 80: 902-909.

Lewis, R., T.C. O'Connell, M. Lewis, C. Campagna and A.R. Hoelzel. - 2006. Sex-specific foraging strategies and resource partitioning in the southern elephant seal (Mirounga leonina). Proc. R. Soc., B, 273: 2901-2907.

Lorrain, A., N. Savoye, L. Chauvaud, Y. Paulet and N. Naulet. 2003. Decarbonation and preservation method for the analysis of organic $\mathrm{C}$ and $\mathrm{N}$ contents and stable isotope ratios of lowcarbonated suspended particulate material. Anal. Chim. Acta, 491: $125-133$

McMahon, C.R., H.R. Burton and M.N. Bester. - 2000. Weaning mass and the future survival of juvenile southern elephant seals, Mirounga leonina, at Macquarie Island. Antarct. Sci., 12: 149-153.

Merrick, R.L. and T.R. Loughlin. - 1997. Foraging behavior of adult female and young-of-the-year Steller sea lions in Alaskan waters. Can. J. Zool., 75: 776-786.

Michener, R.H. and D.M. Schell. - 1994. Stable isotope ratios as tracers marine aquatic food webs. In: K. Lajtha and R.H. Michener (eds.), Stable isotopes in ecology and environmental science, pp. 138-157. Blackwell, Oxoford.

Moore, J.W. and B.X. Semmens. - 2008. Incorporating uncertainty and prior information into stable isotope mixing models. Ecol. Lett., 11: 470-480.

Ogawa, N. and N. Ogura. - 1997. Dynamics of Particulate Organic Matter in the Tamagawa Estuary and Inner Tokyo Bay. Est. Coast. Shelf Sci., 44: 263-273.

Parnell, A., R. Inger, S. Bearhop and A.L. Jackson. - 2008. SIAR: Stable Isotope Analysis in R. http://cran.r-project.org/web/packages/siar/index.html.

Reid, K. and J. Forcada. - 2005. Causes of offspring mortality in the Antarctic fur seal, Arctocephalus gazella: the interaction of density dependence and ecosystem variability. Can. J. Zool., 83: 604-609.

Riedman, M. - 1990. The pinnipeds: seals, sea lions, and walruses. 
598 - M. DRAGO et al.

University of California Press, Berkeley.

Soto, K.H., A.W. Trites and M. Arias-Schreiber. - 2004. The effects of prey availability on pup mortality and the timing of birth of South American sea lions (Otaria flavescens) in Peru. J. Zool., 264: 419-428.

Soto, K.H., A.W. Trites and M. Arias-Schreiber - 2006. Changes in diet and maternal attendance of South American sea lions indicate changes in the marine environment and prey abundance. Mar. Ecol. Prog. Ser., 312: 277-290.

Thompson, D., C.D. Duck, B.J. McConnell and J. Garrett. - 1998. Foraging behaviour and diet of lactating female southern sea lions (Otaria flavescens) in the Falkland islands. J. Zool., 246: 135-146.
Werner, R. and C. Campagna. -1995. Diving behaviour of lactating southern sea lions (Otaria flavescens) in Patagonia. Can. J. Zool., 73: 1975-1982.

Werner, R., A.-L. Figueroa-Carranza and C.L. Ortiz. - 1996. Composition and energy content of milk from southern sea lions (Otaria flavescens). Mar. Mamm. Sci., 12: 313-317.

Scient. ed.: D. Oro.

Received September 1, 2009. Accepted January 11, 2010.

Published online May 28, 2010. 